\title{
Determining Performance and Application of Steady-State Models and Lagrangian Puff Model for Environmental Assessment of CO and $\mathrm{NO}_{\mathrm{x}}$ Emissions
}

\author{
Kazım Onur Demirarslan ${ }^{1 *}$, Şenay Çetin Doğruparmak² \\ ${ }^{1}$ Department of Environmental Engineering, Artvin Çoruh University, \\ 08000 Artvin, Turkey \\ ${ }^{2}$ Department of Environmental Engineering, Kocaeli University, \\ 41380 Kocaeli, Turkey
}

Received: 18 May 2015

Accepted: 8 September 2015

\begin{abstract}
Air quality modellings are highly useful systems used to investigate the possible impact of emissions diffusing into the atmosphere in any area they might have on that area. There are many modelling methods whose capacities are limited by their advantages and disadvantages or the equipment they use. In this study, therefore, both steady-state models (AERMOD and ISCST-3) and the Lagrangian model (CALPUFF) are used. This study has two purposes: one is to specify performance of the models. Performances were determined with various statistical methods such as fractional bias (FB), mean squared error (MSE), and geometric mean bias (MG). The other purpose of this study is to evaluate temporal and spatial variations of point $(\mathrm{P})$, area (A), and line (L) - sourced $\mathrm{CO}$ and $\mathrm{NO}_{\mathrm{x}}$ emissions in the research area by using the modelling methods. The district of Körfez, which is one of the districts of the province of Kocaeli, was chosen as the study area.

When the results obtained with modelling all $\mathrm{P}$ and A sources by three programs are analyzed, the highest annual concentration AERMOD, ISCST-3, and CALPUFF were found as 128.82, 86.96, and $201.30 \mu \mathrm{g} / \mathrm{m}^{3}$ for $\mathrm{CO}$, and 7.56, 26.31, and $6.10 \mu \mathrm{g} / \mathrm{m}^{3}$ for $\mathrm{NO}_{\mathrm{x}}$, respectively. On the other hand, when the results obtained with modelling all $\mathrm{P}$ and $\mathrm{A}$ and $\mathrm{L}$ sources by two programs are investigated, the highest annual concentration AERMOD and ISCST-3 were found to be 155.12, $92.46 \mu \mathrm{g} / \mathrm{m}^{3}$ for CO, and 166.93 and $89.98 \mu \mathrm{g} / \mathrm{m}^{3}$ for $\mathrm{NO}_{\mathrm{x}}$, respectively. When contributions of the pollutant sources on pollution are evaluated, it was observed that area sources and line sources are more predominant than other sources for $\mathrm{CO}$ and $\mathrm{NO}_{\mathrm{x}}$ emissions.

It was observed by analyzing the diffusion maps that residential areas in the district are more concentrated. Therefore, in the study the predicted and observed values were also compared with national and international limit values and determined to meet these limit values. According to the results obtained by evaluation of performances of the models with FB, MS, and MG statistical methods, performance sorting for $\mathrm{NO}_{\mathrm{x}}$ emissions was found to be ISCST-3 > CALPUFF > AERMOD, while for CO emissions it is given as
\end{abstract}

*e-mail: onurdemirarslan@artvin.edu.tr 
CALPUFF $>$ AERMOD $>$ ISCST-3. However, since it is not correct to distinguish between performance of a model for an application and that of another model accurately, performances of the models were interpreted according to the results of this study and literature review.

Keywords: steady-state models, Lagrangian puff model, Körfez district, $\mathrm{CO}$ and $\mathrm{NO}_{\mathrm{x}}$ emissions

\section{Introduction}

Air pollution is one of the most important environmental factors affecting quality of life and health. Toxic compounds having complex structures found in urban atmosphere may lead to acute and chronic health problems in vulnerable groups such as children and those who have already undergone cardiac and respiratory disorders [1-2]. Outdoor air pollution caused 3.2 million deaths and also the loss of 76 million lives all around the world in 2010. In addition, a significant point is that air pollution occurring in a region does not appear in only that region but also propagates, depending on the meteorological events, and leads to global problems (such as global warming, acid rain, etc.). Therefore, developing countries are working hard to reduce air pollution, and protect and improve air quality [3-4].

Various methods such as measurement, emission inventory, and modelling studies are used in order to determine impacts of air pollution caused by one or more pollutants found at high levels in the atmosphere on the receiving environment and to monitor whether pollutant concentrations exceed the legal limit values. Air pollution measurement data are important in regards comparing with the national and international legal limit values and determining whether certain pollutants exceed the legal limit values. On the other hand, emission inventories are useful tools from the point of identification of individual amounts of emissions diffusing into the atmosphere from various pollutant sources such as residential heating, traffic, and industry,and making comparison between those pollutant sources [5]. Air quality modellings are important for estimating the atmospheric concentrations of pollutants and determining their distribution.

Development of all models contains a number of different steps, such as scientific evaluation, code writing, model validation, and sensitivity analysis [6]. Distribution models can calculate the air pollution concentrations by using emission, meteorological, and topographical data. Although time requirements and data entries are difficult for the calculations, successful estimations can be made in regards to distributions [7-9]. Atmospheric distribution is a complex process that varies depending on topography, meteorology, emissions, and land use. In recent years these data have been systematized in air quality modellings and increasingly used in complex estimations of concentrations in air. However, despite the complexities behind these developed models, accuracy and precision in the results are associated with the emission inventories generally used as input data in the model [10].
Various modelling approaches can be used for modelling of atmospheric distributions of pollutants [11]. Capacities of the modelling methods can vary. Although only a certain number of mathematical formulas run on background of each model, differences occur in estimations and programs calculate different results. Therefore, one aim of the present study is to specify performances of the models by using both steady-state models (AERMOD and ISCST-3) and the Lagrangian puff model (CALPUFF). For this aim, results of the models were compared with the results of measurements performed with the active method in the mobile measurement vehicle available in the research area and, then, performances were determined with various statistical methods. Considering the studies made in recent years, it can be seen that statistical methods have been widely used. The greater number of analysis methods used for any study performed, the greater the accuracy coefficient of the result considered to be achieved [12]. Based on this approach, in this study fractional bias (FB), mean squared error (MSE), and geometric mean bias (MG) methods were used as the statistical method. The other aim of this study is to evaluate temporal and spatial variations of point $(\mathrm{P})$, area $(\mathrm{A})$ and line (L) -sourced $\mathrm{CO}$ and $\mathrm{NO}_{\mathrm{x}}$ emissions in the research area by using the modelling methods.

The district of Körfez, which is one of the districts of the province of Kocaeli, was chosen as the study area. Its population reached 129,110 in 2008 - up from about 2,000-3,000 in the 1960s [13]. Population growth has led to a boom in construction activities, an increase in the number of vehicles and traffic density, and an increase in the number of industrial plants. These outcomes remain some the main causes of air pollution in the district. Exposure to air pollutants leads to serious side-effects. Therefore, it is important to take the necessary precautions for monitoring and reducing the pollutants.

It is expected that the results obtained by this study will contribute to the evaluation of advantages and disadvantages of AERMOD, ISCST-3, and CALPUFF models, and to the studies aimed at determining air quality in the study area.

\section{Material and Methods}

\section{Study Area}

The district of Körfez, which is the study area (Fig. 1), is one of the seven districts of Kocaeli located in the Marmara Region, and its surface area is $398 \mathrm{~km}^{2}$. The district was 
built on a plain. It has a greenspace ratio of approximately $40 \%$ while its settlement ratio is $60 \%$. Population density is high at the coastline and decreases gradually as one moves inland. It has 15 villages, 11 neighborhoods, and a total of 865 street and main roads. The number of buildings and residences in the district center are 14,150 and 29,128, respectively. There are 3,864 business offices (including industrial organizations) in the district. It is a logistics location not only for its industry but also port and piers existing within its structure. In addition to all these, the District of Kocaeli is a passageway between Europe, Asia, and the Middle East through the railway, the D-100 highway, and the TEM motorway [14].

\section{Modelling Methodology}

\section{Atmospheric Transport Models}

\section{AERMOD}

The AERMOD modelling program used in the study is an experimental, refined, Gaussian steady-state model and can calculate plume distributions in order to evaluate the inert pollutants emitted into the atmosphere from different sources in terms of air quality [16-18]. AERMOD makes distribution calculations by using the meteorological characteristics of the study area, including data such as chimney height and diameter, emission temperature, pollutant exit velocity and air temperature turbulence, and wind speed and direction, and can be used in rural and urban areas, plain and complex terrains, and in multiple sources such as point, line, area, and volume [8-18]. The AERMOD program needs hourly surface and upper air layer data in order to be able to make these calculations [9]. The program includes algorithms that can calculate the Planetary Boundary Layer parameters with data such as friction velocity, Monin-Obukhov length, transmission speed and temperature scale, mixing height, and surface heat flux. Furthermore, this program can be used in studies conducted at simple and plain terrains as well as complex terrains [9-19]. AERMOD is composed of two scripts including AERMAP (a terrain data preprocessor) and AERMET (a meteorological data preprocessor).

\section{ISCST-3}

This model is based on Gaussian plume equality, which is the simplified form of the three-dimensional transmission-distribution equation, and it can calculate the pollutant concentrations at ground level annually, daily, and hourly by using area-specific hourly meteorological data. In addition, the model can use real-time variable meteorological conditions and elevated source data. The program can predict the concentration or accumulation values in each source-receptor combination and, for this aim, it can include into the calculations the effects of topographical structure of the terrain, source properties, variations in pollutant emission rate, reduction in pollutants, and buildings on Plume distribution [2021]. The most important advantage compared to other distribution models is that it is relatively easy to use and the meteorological data file required for the model is relatively small. And its disadvantage is that information on the structure of the atmospheric boundary layer and estimation of the associated turbulent distribution process are not included in the model [22].

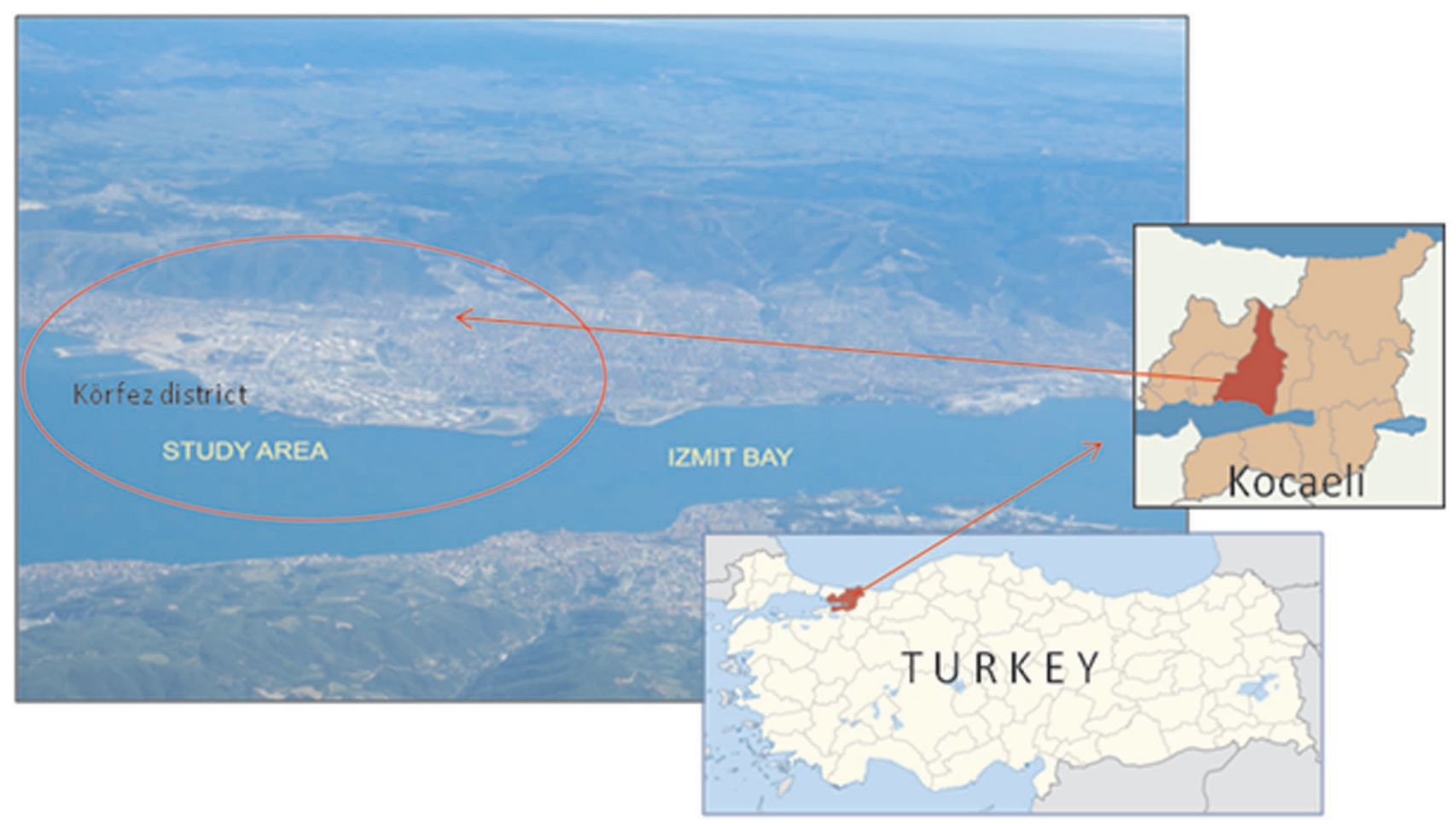

Fig. 1. Topview image of the study area [15]. 
Table 1. The input data used in the dispersion model.

\begin{tabular}{|c|c|c|c|}
\hline \multirow[t]{2}{*}{ Input Data } & \multicolumn{3}{|c|}{ Program } \\
\hline & AERMOD & ISCST-3 & CALPUFF \\
\hline Land use & $\% 40$ rural, $\% 60$ urban & $\% 40$ rural, $\% 60$ urban & calculated by CALPUFF \\
\hline & $\begin{array}{c}\text { In Rural Area; } \\
\% 50 \text { cultivates land, } \% 50 \text { grassland }\end{array}$ & $\begin{array}{c}\text { In Rural Area; } \\
\% 50 \text { cultivates land, } \% 50 \text { grassland }\end{array}$ & calculated by CALPUFF \\
\hline Receptors & 1,250 uniform cartesian & 1,250 uniform cartesian & 1,250 uniform cartesian \\
\hline Surface roughness length & 0.62 & 0.62 & calculated by CALPUFF \\
\hline Albedo & 0.2145 & 0.2145 & calculated by CALPUFF \\
\hline Bowen rate & 1.89 & 1.89 & calculated by CALPUFF \\
\hline Distribution coefficient & Urban & Urban & calculated by CALPUFF \\
\hline Terrain coefficient & Simple+complex & Simple + complex & calculated by CALPUFF \\
\hline Time option & $24 \mathrm{~h}$ and annual & $24 \mathrm{~h}$ and annual & $24 \mathrm{~h}$ and annual \\
\hline Map & dwg extension & dwg extension & dwg extension \\
\hline Meteorological data & $\begin{array}{l}\text { 2005-2009 } \\
\text { hourly surface and upper air met data }\end{array}$ & $\begin{array}{l}\text { 2005-2009 hourly surface air met } \\
\text { data }\end{array}$ & $\begin{array}{l}\text { 2005-2009 hourly surface } \\
\text { and upper air met data }\end{array}$ \\
\hline Source data & $\begin{array}{l}\text { - Point sources } \\
\text { - Area sources } \\
\text { - Line sources }\end{array}$ & $\begin{array}{l}\text { - Point sources } \\
\text { - Area sources } \\
\text { - Line sources }\end{array}$ & $\begin{array}{l}\text { - Point sources } \\
\text { - Area sources }\end{array}$ \\
\hline
\end{tabular}

\section{CALPUFF}

CALPUFF is a meteorology/air quality modelling program developed by the Atmospheric Studies Group and also tested by the U.S. EPA, which is suggested for general scale applications in case long-distance transports, coastal areas, or complex surface area effects exist [23-24]. The program is a non-steady state puff distribution model. It can calculate impacts of meteorological conditions that vary over time as a result of area effect on transport, removal, and chemical conversions of the pollutants [2526]. Furthermore, the program also includes algorithms based on the distribution coefficient approach and dry-wet accumulation model [27]. CALPUFF splits the pollutants into a large number of different cells (puff) and each cell is influenced regardless of terrain conditions, meteorological conditions, chemical conversions, accumulations, and, in particular, time intervals [28]. The CALPUFF modelling program consists of three main components, including CALMET, CALPUFF, and CALPOST [23].

\section{Input Data Used}

The data summarized in Table 1 were entered to modelling programs as input.

\section{Meteorological Data}

The models used in this study use annual data on an hourly basis as the meteorological data. In these models, meteorological data up to a maximum of five years can be used. Five-year data (2005-09) has been used in the study, thinking that the use of more meteorological data will enhance the accuracy in the forecast [29]. The hourly meteorological data recorded by "Lakes Environmental Software" were used in the ISCST-3 model. These data include hourly temperature, wind velocity, wind direction, air pressure, cloud height, and precipitation measurements per day. The obtained meteorological data were processed by the RAMMET View program, which is a pre-processor of the ISCST-3 modelling program. Because the mixture heights were not valued, these data were calculated by RAMMET View, which is a pre-processor program. Wind data were processed by the WRLPLOT, which is a processor under the ISCST-3 model. The wind rose obtained with the assistance of this program for 2005-09 is shown in Fig. 2. AERMOD and CALPUFF models use the meteorological data used for the ISCST-3 modelling program and upper air meteorological data. These

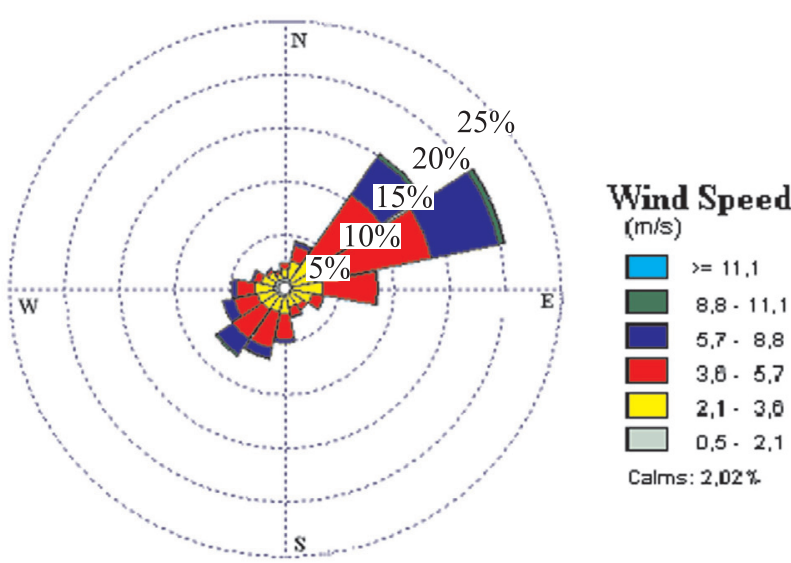

Fig. 2. The wind rose, prepared by WRLPLOT. 
meteorological data obtained from these programs were provided by CALMET (which is a pre-processor of CALPUFF) and AERMET View (which is a pre-processor of AERMOD) modelling programs.

\section{Emission Sources}

In this study, point sources of $\mathrm{CO}$ and $\mathrm{NO}_{\mathrm{x}}$ emissions were assessed for 20 and 15 industrial plants, respectively, in the territorial district. The data related to the industrial plants and their emission rates were obtained from the Kocaeli Provincial Directorate of Environment and Urbanization. The used data are the number of factory chimneys, the height of a factory chimney (m), flue gas velocity $(\mathrm{m} / \mathrm{s})$ and temperature $(\mathrm{K})$, inner diameter of the chimney $(\mathrm{m})$, and pollutant concentration $(\mathrm{g} / \mathrm{s})$. It has paid attention to the use of 2008 data, but the reports covering 2009 and five years prior have been evaluated since available emission reports for all facilities do not belong to 2008 [30].

As area resources, residential areas of the district were assessed. The residential areas were divided into 4 different areas because the construction rate of the district is $60 \%$ and the green area rate is $40 \%$. The approximate areas of residential areas $1,2,3$, and 4 as calculated on the map were 1,100,121.7, 2,206,175.5, 893,721.1, and $1,118,526 \mathrm{~m}^{2}$, respectively. The pollutant emission rates from these sources were calculated based on the population and the amounts of different fuels consumed for residential heating in each area [31], based on the massbased [32] emissions factors of the U.S. Environmental Protection Agency.

Regarding the district's line sources, the TEM highway, which is approximately $25 \mathrm{~km}$ long, and the
D-100 State Road, which is approximately $20 \mathrm{~km}$ long, were evaluated. The numbers of vehicles traveling these roads daily were derived from existing reports [33]. A "Line source" option is available for the calculation of distribution of emissions from the roads in AERMOD and ISCST-3 programs. Nonetheless, the "line source" option in version 5.8 of the CALPUFF VIEW program prepared by Lakes Environmental Software 2003 2010 is different from the options in AERMOD and ISCST-3 programs. The "line source option" in the CALPUFF VIEW 5.8 program is defined as a "Buoyant Line Source." As an example, the source for the use of this option can be turned over the air vents on the caps of steel-iron smelting plants. Thus, the CALPUFF program was not employed for computing the distributions emerging from linear sources.

The line, area, and point sources entering the modelling program are presented in Fig. 3.

\section{Observation Method}

Measurements of $\mathrm{CO}$ and $\mathrm{NO}_{\mathrm{x}}$ concentrations were performed with the active method. $\mathrm{CO}$ and $\mathrm{NO}_{\mathrm{x}}$ concentrations taken from the station are as daily means and measurement results are for one year (December 2007 to November 2008). The method of measuring the concentration of $\mathrm{CO}$ is the infrared absorption principle associated with gas filter, while the method for measuring the concentration of $\mathrm{NO}_{x}$ is the chemiluminescence method.

\section{Statistical Method}

Results of estimations and results of measurements were compared using different statistical methods in order

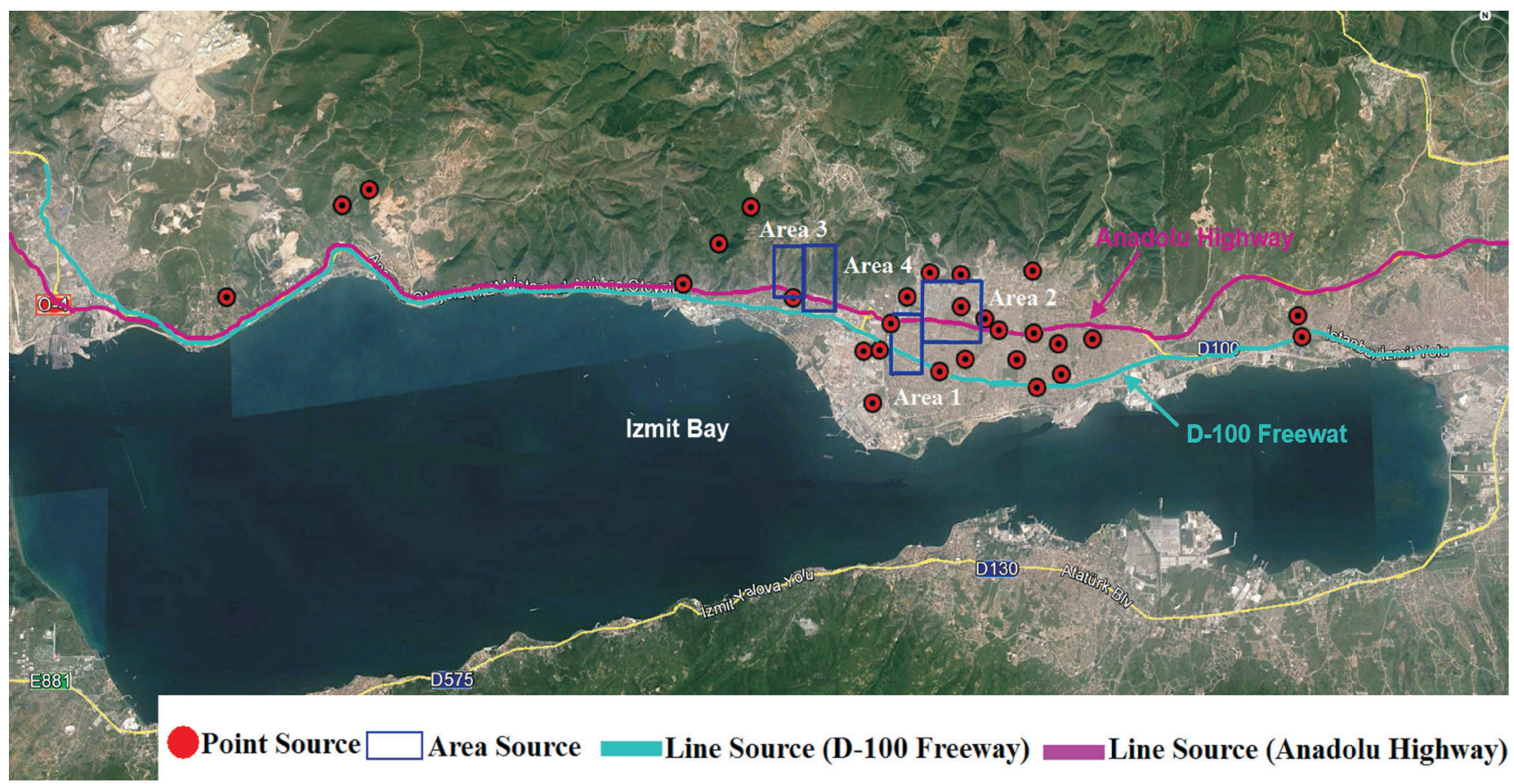

Fig. 3. Point, area, and line sources in Korfez District [15]. 
to be able to determine the performances of the modelling programs. The methods used were: "fractional bias (FB)," "mean squared error (MSE)," and "geometric mean bias (MG)."

The FB method was given in Equation 1, which $\mathrm{C}_{\mathrm{o}}$ and $\mathrm{C}_{\mathrm{p}}$ are the observed concentration and predicted concentration values, respectively. The ideal value for $\mathrm{FB}$ is 0 ; however, the interval for the obtained results may be between -2.00 (overestimation) and +2.00 (underestimation) [34-37]. According to Chang and Hanna (2003), suitability of a model could be mentioned if $\mathrm{FB}$ value were calculated between -0.7 and +0.7 [38].

$$
F B=\frac{2\left(\bar{C}_{o}-\bar{C}_{p}\right)}{\bar{C}_{o}+\bar{C}_{p}}
$$

The other method of comparison is the mean squared error (MSE) given in equation (2). Results obtained here are dimensionless. It means that model and measurement results get closer to each other if the result is found to be less than 0.5 .

$$
M S E=\frac{\left(\bar{C}_{p}-\bar{C}_{o}\right)}{\bar{C}_{p} \bar{C}_{o}}
$$

Another comparison method is the "geometric mean bias (MG)" given in Equation (3). MG value is linear and, here, degree of error of geometric mean is represented rather than the arithmetic mean. In the results, $\mathrm{MG}<0.25$ represents underestimation and $\mathrm{MG}>4$ shows overestimation, and this value should be 1 for a good modelling [39].

$$
M G=\exp \left(\overline{\ln C_{o}}-\overline{\ln C_{p}}\right)
$$

a)

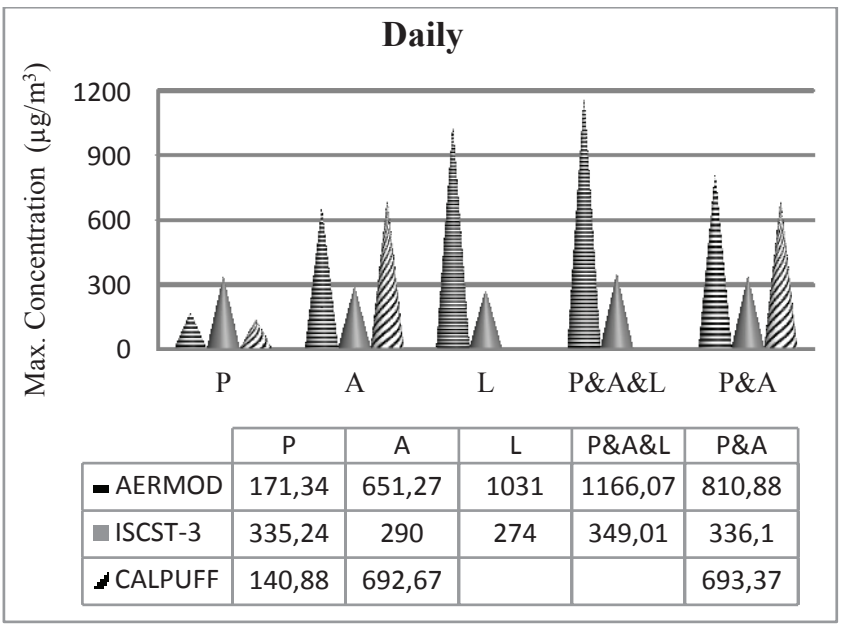

\section{Results and Discussion}

Modelling Results

\section{CO Distributions}

Distribution modelling of $\mathrm{CO}$ was performed two different ways, including modelling of emissions composed of point+area+line (P\&A\&L) sources with AERMOD and ISCST-3, and modelling of emissions composed of point+area (P\&A) sources with AERMOD, ISCST-3, and CALPUFF. The results obtained and the distribution maps are given in Figs 4-6.

Having analyzed the modelling results, it is observed that the highest concentration values calculated by each program at different times are different from each other (Fig. 4). When the results obtained with modelling of all P\&A\&L and P\&A sources are investigated, it is specified that the highest concentration values calculated by ISCST- 3 at all times are less than those results given by other programs used for comparison. On the other hand, it is determined that the program giving the maximum concentration value varies with the time option. It is specified to be CALPUFF according to the annual concentration results, and AERMOD according to the daily concentration results.

When contributions of the pollutant sources on pollution are evaluated with respect to the annual max. concentrations, it was observed that point sources, area sources, and line sources are predominant with a rate of $17.61 \%, 45.62 \%$, and $36.76 \%$, respectively, according to the AERMOD program; point sources, area sources, and line sources are predominant with a rate of $33.08 \%$, $40.86 \%$, and $26.05 \%$, respectively, according to the ISCST-3 program, and point sources and area sources are predominant with a rate of $12.18 \%$ and $87.81 \%$, respectively, according to the CALPUFF program. These results indicate that area sources with respect to $\mathrm{CO}$ are predominant according to each of the three programs, although numerical values calculated according to the modelling programs change.

b)

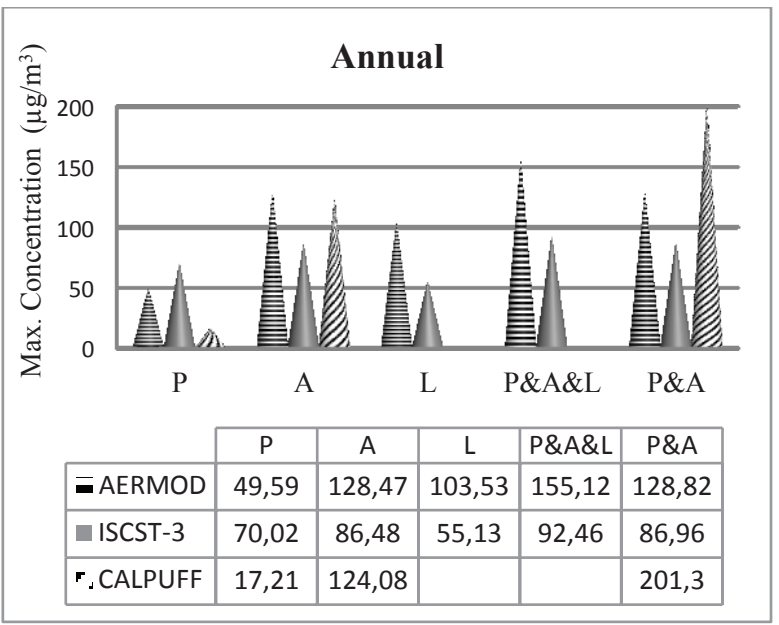

Fig. 4. The modelling results for $\mathrm{CO}$ a) daily, b) annual. 
a)

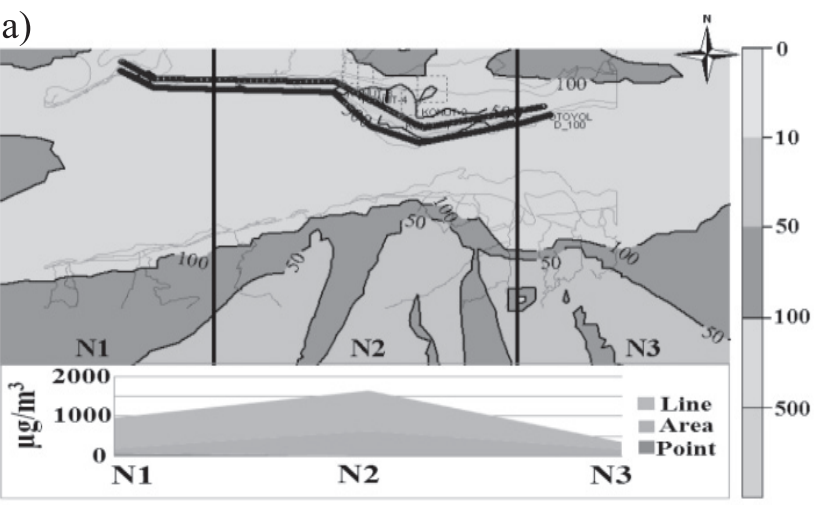

AERMOD-daily

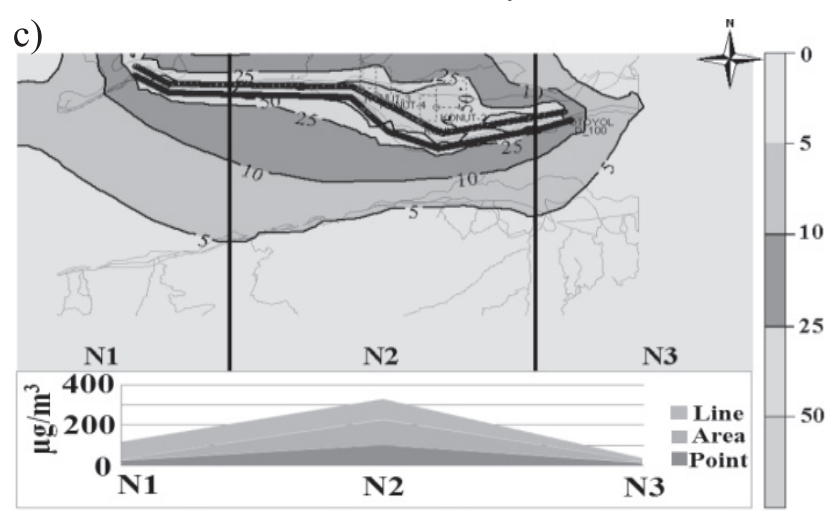

AERMOD-annual b)

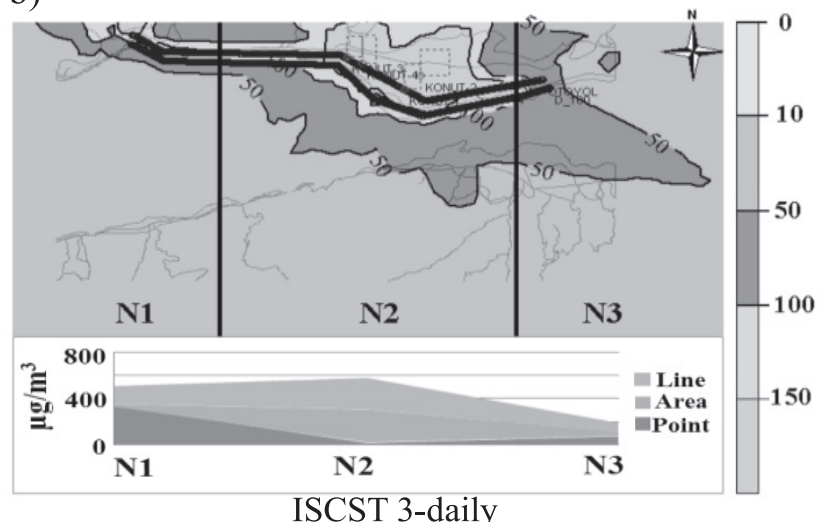

d)

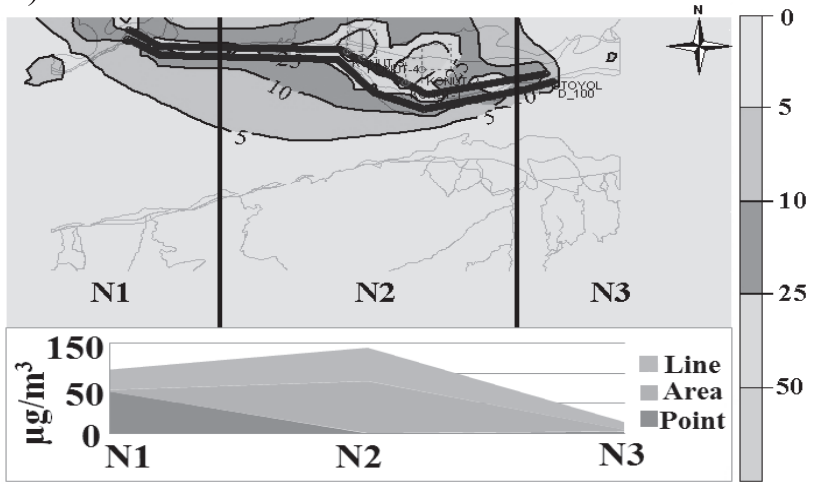

ISCST 3-annual

Fig. 5. Estimated distributions of CO emissions (P\&A\&L) a) AERMOD-daily, b) ISCST 3-daily, c)AERMOD-annual, d) ISCST 3-annual.

a)

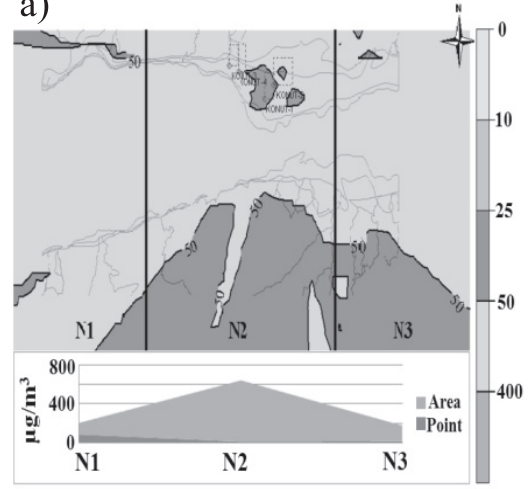

AERMOD-daily

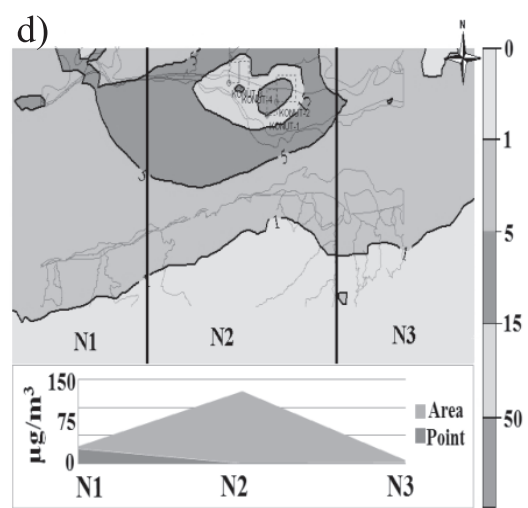

AERMOD-annual b)

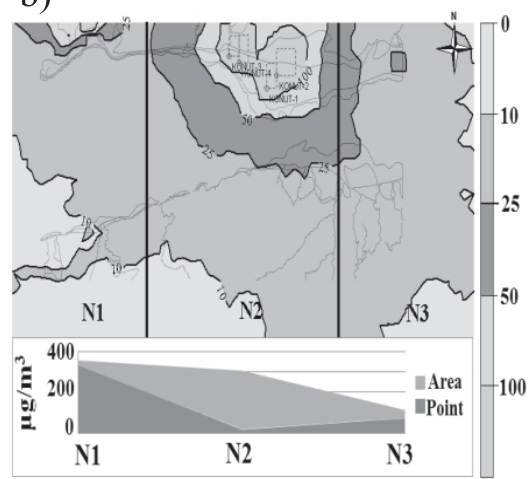

ISCST 3-daily

e)

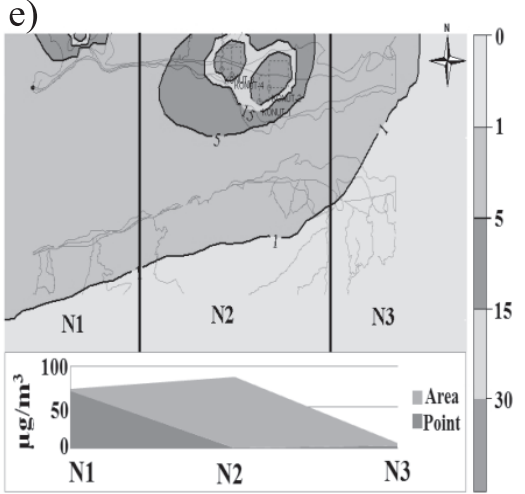

ISCST 3-annual c)

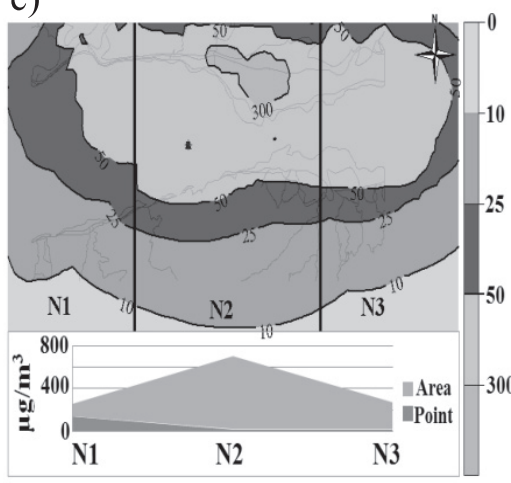

CALPUFF-daily

f)

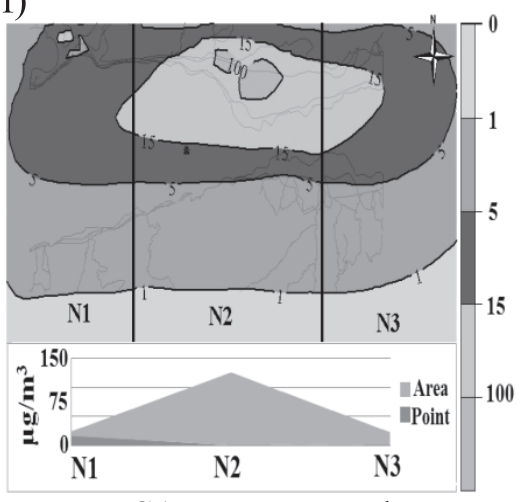

Fig. 6. Estimated distributions of CO emissions (P\&A) a) AERMOD-daily, b) ISCST 3-daily, c) CALPUFF-dail , d) AERMOD-annual, e) ISCST 3-annual, f) CALPUFF-annual. 
When the distribution maps were analyzed (Figs. 5 and 6), it was determined that both P\&A\&L- and P\&Asourced $\mathrm{CO}$ emissions center around the area N2 in the distribution maps.

\section{NO $O_{x}$ Distributions}

$\mathrm{NO}_{\mathrm{x}}$ emissions in the study area are composed of all three sources, including point, area, and line. Therefore, P\&A\&L sources were modelled with AERMOD and ISCST-3 programs, and emissions composed of P\&A sources were modelled with AERMOD, ISCST-3, and
CALPUFF programs. The results obtained and the distribution maps are given in Figs 7-9.

Having analyzed the modelling results (Fig. 7), it has been observed that AERMOD has a higher concentration value according to the results obtained by modelling of P\&A\&L sources. On the other hand, the ISCST-3 program calculated a higher concentration value according to the results obtained by modelling of P\&A sources. It is observed that AERMOD and CALPUFF VIEW programs give approximately the same values for the annual time option.

b)

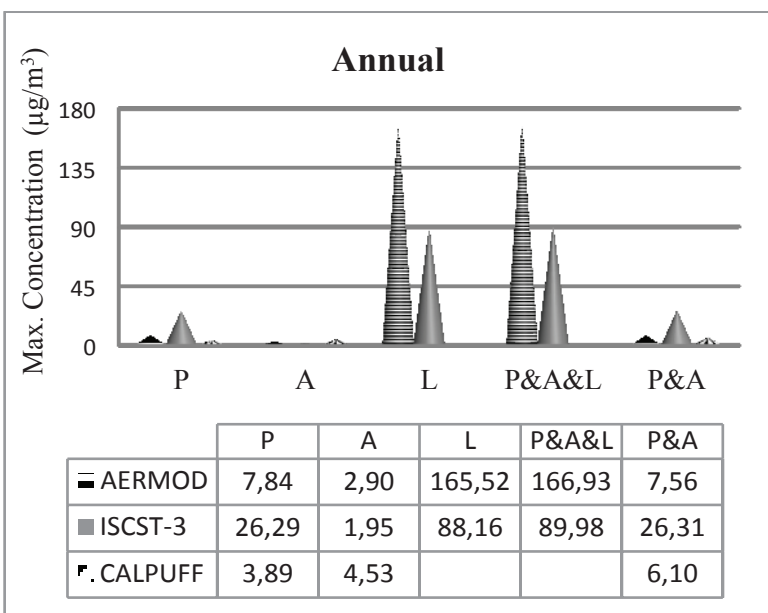

Fig. 7. The modelling results for $\mathrm{NO}_{x}$ a) daily, b) annual.

a)

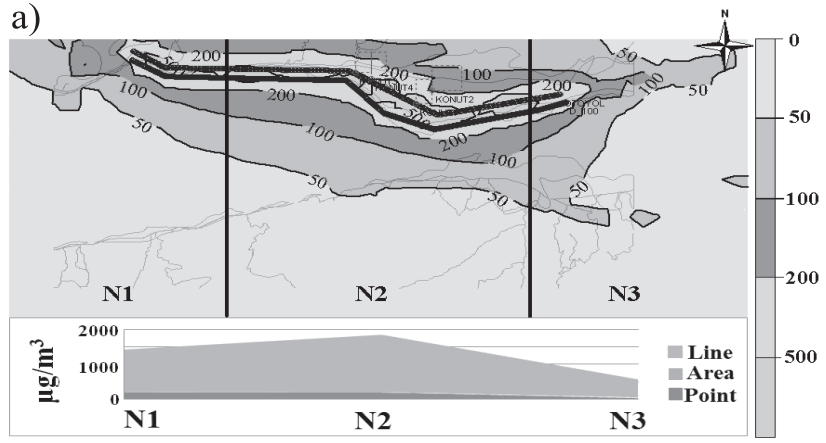

AERMOD-daily

c)

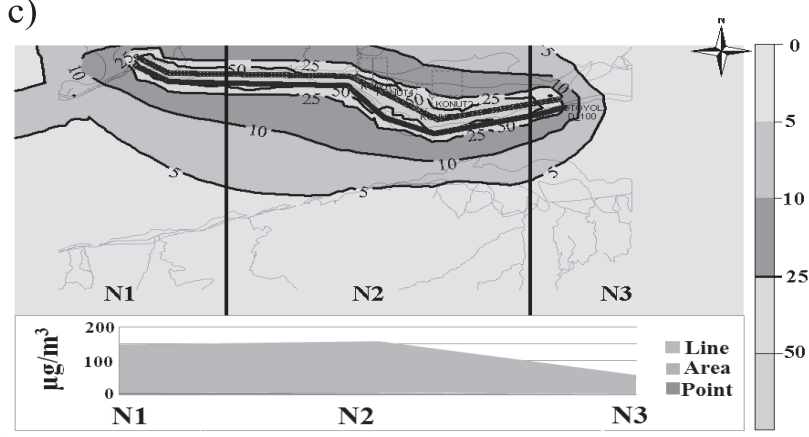

AERMOD-annual b)

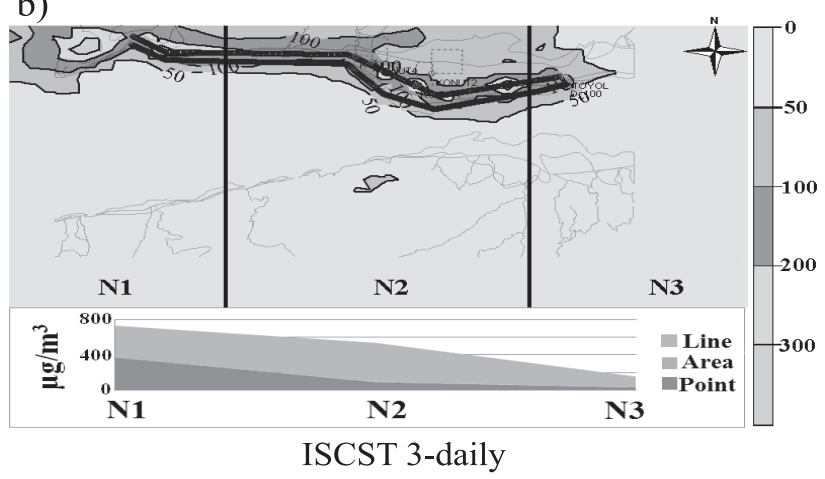

d)

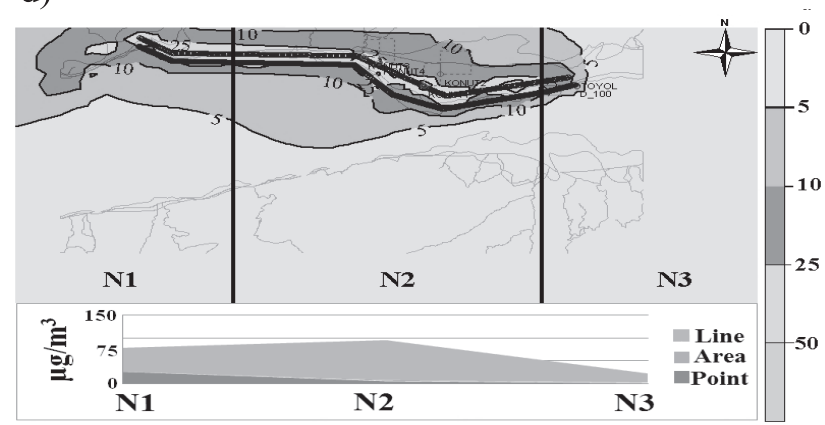

ISCST 3-annual

Fig. 8. Estimated distributions of NOx emissions (P\&A\&L) a) AERMOD-daily, b) ISCST 3-daily, c)AERMOD-annual, d) ISCST 3-annual. 
a)

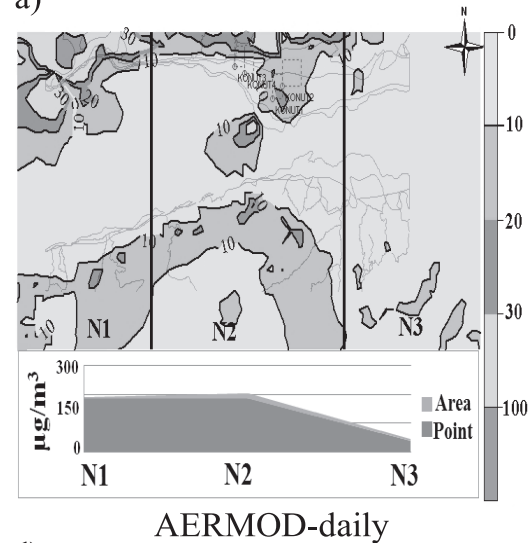

d)

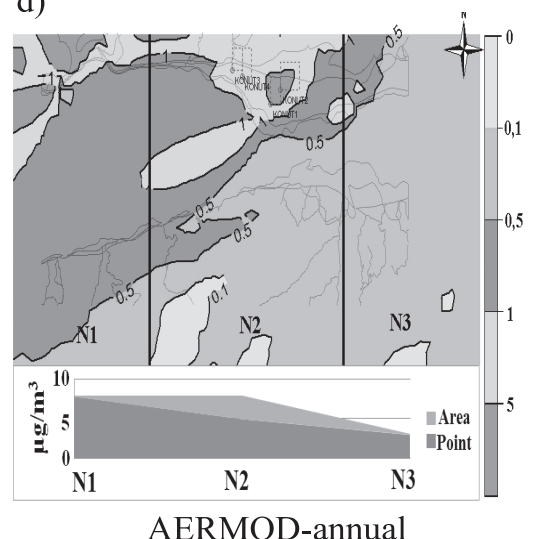

b)

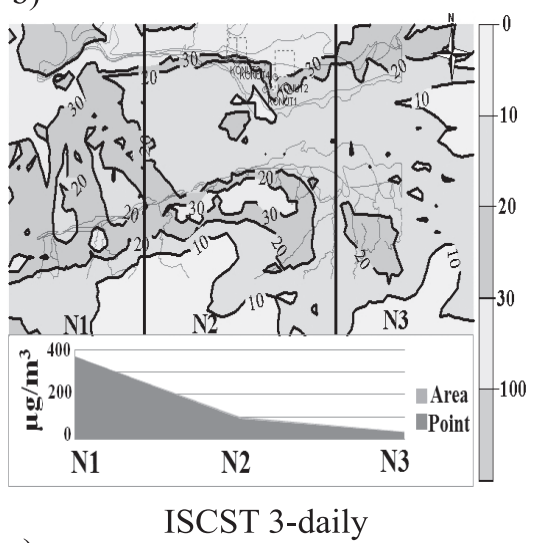

e)

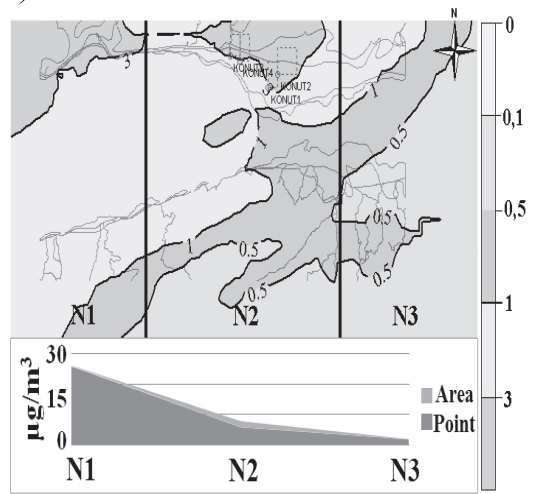

ISCST 3-annual c)

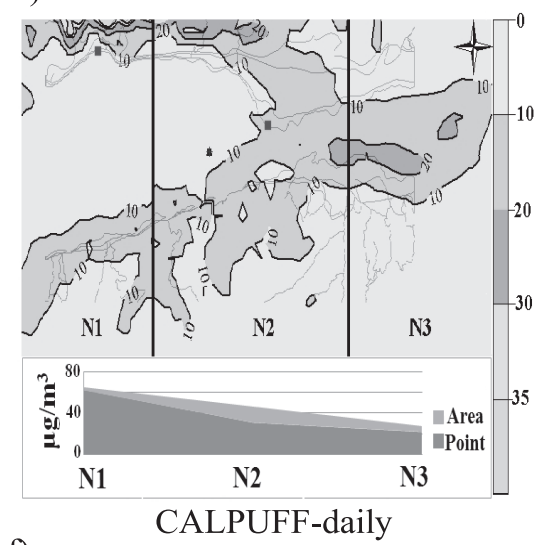

f)

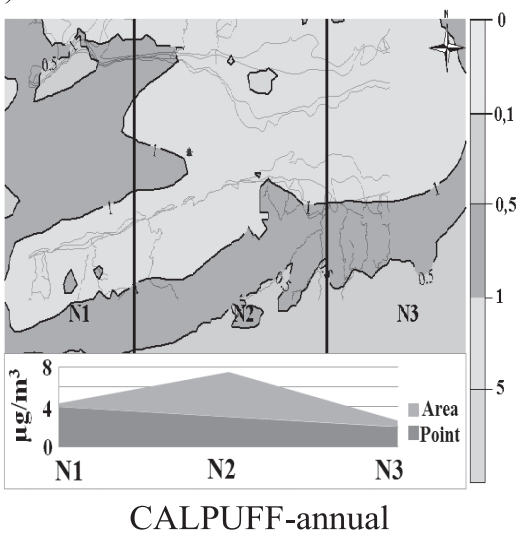

Fig. 9. Estimated distributions of $\mathrm{NO}_{\mathrm{x}}$ emissions (P\&A) a) AERMOD-daily, b) ISCST 3-daily, c) CALPUFF-dail, d) AERMOD-annual, e) ISCST 3-annual, f) CALPUFF-annual.

When contributions of the pollutant sources on pollution are evaluated with respect to the annual maximum concentrations, it was observed that point sources, area sources, and line sources are predominant with rates of $4.4 \%, 1.64 \%$, and $93.9 \%$, respectively, according to the AERMOD program; point sources, area sources, and line sources are predominant with a rate of $28.53 \%, 2.11 \%$, and $95.68 \%$, respectively, according to the ISCST-3 program, and point sources and area sources are predominant with a rate of $46.19 \%$ and $53.80 \%$, respectively, according to the CALPUFF program. These results indicate that line sources with respect to $\mathrm{NO}_{\mathrm{x}}$ are predominant according to each of the two modelling programs.

When the distribution maps are analyzed (Figs 8 and 9), it is determined that both P\&A\&L- and P\&A-sourced $\mathrm{NO}_{\mathrm{x}}$ emissions center around the areas $\mathrm{N} 1$ and $\mathrm{N} 2$ in the distribution maps.

\section{Evaluation of Model Performances}

Daily maximum concentrations of the estimated and observed values were used for the statistical methods used for evaluating program performances. Daily concentrations were preferred rather than the annual concentrations, although measurement results were for one year because a considerable amount of data loss was observed when measurement results for one year were investigated. This was considered to influence evaluation of performance. In order to specify the estimated concentration for comparison, coordinates of the point where the active measurement was performed was determined and concentration values at the receiving point corresponding to this coordinate were taken as a basis in the model programs. The results obtained are given in Table 2.

When the results obtained by modelling all of P\&A\&L and P\&A sources are investigated by referring to Table 5, it is observed that FB values vary between -1.3 1.8, MSE values between 0.2 17.05, and MG values between $0.01 \sim 5.37$. It can be seen that both overestimations and underestimations exist according to the modelling programs and type of pollutant when the acceptable range for each statistical method is investigated in the same table. The difference between the modelling programs and the observed value was also encountered in the studies conducted previously $[34,36,38,40]$. Conditions that may cause differences in this study can be explained as per the following.

Errors in measurement devices or data loss that cannot be completed can affect the modelling studies in particular in short-term actual measurements [41]. A successful modelling study depends on the detail and accuracy of the inventory at the emission source, as well as the precision of meteorological data in the study area. The reliability 
Table 2. FB, MSE and MG results for predicted and observed values.

\begin{tabular}{|c|c|c|c|c|c|c|}
\hline \multirow{3}{*}{ Source type } & \multirow{3}{*}{ Pollutans } & \multirow{3}{*}{ Programs } & \multirow{3}{*}{$\begin{array}{c}\text { Estimation } \\
\text { (daily max con. } \mu \mathrm{g} / \mathrm{m}^{3} \text { ) }\end{array}$} & FB & MSE & MG \\
\hline & & & & \multicolumn{3}{|c|}{ Acceptable range } \\
\hline & & & & $-2 / \mathrm{FB} /+2$ & $\mathrm{MSE}<0,5$ & $0,25<\mathrm{MG}<4$ \\
\hline \multirow[t]{4}{*}{ P\&A\&L } & $\mathrm{CO}$ & AERMOD & 593.57 & 1 & 4 & 0.18 \\
\hline & & ISCST-3 & 278.77 & 2 & 10 & 0.08 \\
\hline & $\mathrm{NO}_{\mathrm{x}}$ & AERMOD & 691.36 & -1.3 & 3.54 & 5.35 \\
\hline & & ISCST-3 & 201.45 & -0.43 & 0.2 & 1.56 \\
\hline \multirow[t]{6}{*}{ P\&A } & $\mathrm{CO}$ & AERMOD & 376.44 & 1.58 & 6.69 & 0.11 \\
\hline & & ISCST-3 & 169.98 & 1.8 & 17.05 & 0.05 \\
\hline & & CALPUFF & 396.01 & 1.56 & 6.27 & 0.01 \\
\hline & $\mathrm{NO}_{\mathrm{x}}$ & AERMOD & 9.05 & 1.73 & 12.32 & 0.07 \\
\hline & & ISCST-3 & 15.07 & 1.58 & 6.67 & 0.11 \\
\hline & & CALPUFF & 10.61 & 1.69 & 10.2 & 5.37 \\
\hline
\end{tabular}

FB - fractional bias, MSE- mean squared error, MG-geometric mean bias.

of existing inventory prepared under the conditions of our country is controversial. Furthermore, it is quite difficult to piece the available data together.

Complex topographical structure of the study area compared to the performance quality of the Gaussian modellings at plain and flat terrains causes uncertainty in the modelling results [42]. This is because steady-state Gaussian models accept that transport varies linearly as a function of time and space. This approach is not well suited for complex terrains due to non-homogeneity of wind areas, uncertainties contained within altitude values, coastal evaporation, and geographical effects [43]. In addition, turbulence predictions made by the CALMET meteorological model are limited in complex terrains at high altitudes due to the nature of the model [44]. When the study area is evaluated in respect to this, the district has a substantially complex terrain from a topographical point of view. In particular, the northern parts of the district are surrounded by hills at a height up to $600 \mathrm{~m}$, and this height again goes down to sea level within a distance of 5,000 m and may go up to a height of $600 \mathrm{~m}$ once again toward the southern parts of the district. This feature of the study area causes the meteorological data to become highly variable. This situation can explain the errors in predictions of the modelling programs.

The ISCST-3 program cannot model the pollutant distributions in case wind speeds are low $(<1 \mathrm{~m} / \mathrm{s})$, and in such a case it makes calculations by assuming the wind speed is at least $1 \mathrm{~m} / \mathrm{s}$ [45]. When the meteorological data of the study area is investigated, percent of the wind, which is called as calm wing due to its speed lower than $1 \mathrm{~m} / \mathrm{s}$, was specified to be $2.02 \%$. This situation can also explain

Table 3. The comparison of predicted and observed concentrations of pollutants with national and international standards [51-54].

\begin{tabular}{|c|c|c|c|c|c|c|c|c|c|}
\hline \multirow{3}{*}{ 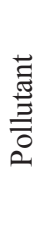 } & \multicolumn{3}{|c|}{$\begin{array}{c}\text { Predicted } \\
\text { (annual max. conc. }-\mu \mathrm{g} / \mathrm{m}^{3} \text { ) }\end{array}$} & $\begin{array}{c}\text { Observed } \\
\left(\mathrm{LTV}^{*}-\mu \mathrm{g} / \mathrm{m}^{3}\right)\end{array}$ & \multicolumn{5}{|c|}{ Limit Values $\left(\mu \mathrm{g} / \mathrm{m}^{3}\right)$} \\
\hline & AERMOD & ISCST-3 & CALPUFF & & \multicolumn{2}{|c|}{ AQAMR } & WHO & EU & USEPA \\
\hline & & & & & Limit value & $\begin{array}{l}\text { Transition } \\
\text { period }\end{array}$ & & & \\
\hline ¿ & 128.82 & 86.96 & 201.30 & 757 & $\begin{array}{c}10000 \\
\text { (8 hourly) }\end{array}$ & $\begin{array}{c}10000 \\
\text { (annual) }\end{array}$ & - & $\begin{array}{c}10000 \\
(8 \text { hourly) }\end{array}$ & $\begin{array}{c}40000 \\
\text { (hourly) } \\
10000 \\
\text { (8 hourly) }\end{array}$ \\
\hline$o^{x}$ & 7.56 & 26.31 & 6.10 & $\begin{array}{c}33.56 \\
\left(\text { as } \mathrm{NO}_{2}\right)\end{array}$ & $\begin{array}{c}200 \\
\left(\text { hourly- } \mathrm{NO}_{2} \text { ) }\right. \\
40 \\
\left(\text { annual- } \mathrm{NO}_{2} \text { ) }\right. \\
30 \\
\text { (annual- } \mathrm{NO}_{2} \text { ) }\end{array}$ & $\begin{array}{c}300 \\
(24 \text { hourly- } \\
\left.\mathrm{NO}_{2}\right) \\
100 \\
\left.\text { (annual- } \mathrm{NO}_{2}\right)\end{array}$ & $\begin{array}{c}40 \\
\text { (annual- } \\
\mathrm{NO}_{2} \text { ) }\end{array}$ & 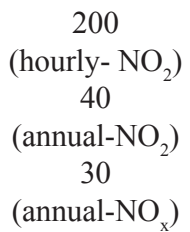 & $\begin{array}{c}100 \\
\text { (annual- } \\
\mathrm{NO}_{2} \text { ) }\end{array}$ \\
\hline
\end{tabular}

*Long Term Value 
part of the uncertainties in the modellings performed with ISCST-3.

When small-scale meteorological areas $\left(<10,000 \mathrm{~km}^{2}\right)$ are used in modellings, fine details such as terrain structure and relationship between water mass/land come into play in meteorological estimations [46]. Modelling programs may sometimes skip these fine details. Study area where the modelling was conducted is approximately $510 \mathrm{~km}^{2}$ and there is a gulf within the area and hills with variable heights surrounding it. Thus, it is considered that terrain structure and relationship between water and land, which are effective in the actual pollution distribution, are not interpreted accurately enough by the modelling programs used.

In this study, landform, altitude values, and land usage used in the CALPUFF program were downloaded from the WEBLAKES web site by entering the coordinates of the modelled area. These data were entered manually into two other programs as heights of receiving point. Only receiving point heights are used for altitude of the terrain in these two programs. This situation is considered to cause differences in the calculations [47].

In some studies, it is specified that long-term predictions of the modelling programs are more consistent than the short-term predictions [48-49]. It is considered that one of the reasons for the differences in calculations may be this situation, since comparisons were performed over concentrations in this study. When it is considered that long-term measurement results are not always available or reliable for reasons such as inability to obtain data on an annual basis as a result of difficulties encountered during measurements or the occurrence of too many disconnections, the necessity for improvement of this feature of distribution algorithms in the programs, which means increasing the reliability of short-term predictions of the modelling programs, is believed to be quite an important issue.

Having evaluated performances of the models under the scope of this study despite the differences between the modelling programs and the observed values, performance sorting for $\mathrm{NO}_{\mathrm{x}}$ emissions was found as ISCST-3> CALPUFF $>$ AERMOD, while for CO emissions they are given as CALPUFF $>$ AERMOD $>$ ISCST-3.

\section{Comparison of the Results with Limit Values}

On the distribution maps we observed that $\mathrm{CO}$ and $\mathrm{NO}_{\mathrm{x}}$ emissions center around the residential areas in the district. Therefore, it is considered that measurement results of the predicted pollutant concentrations and the pollutants measured with active method should be compared with the national and international limit values (Table 3). In general, performance exhibited by the model also increases by an increase in average time options used in the distribution models [50]. For this reason, comparisons were made on an annual basis for the predicted and observed concentrations, and annual maximum values were used for the predicted concentrations while arithmetic mean value of all measurement results were used for the observed concentrations.

When the obtained results were examined (Table 3), the predicted and observed $\mathrm{CO}$ and $\mathrm{NO}_{x}$ concentrations are specified to provide the limit values. However, $\mathrm{NO}_{\mathrm{x}}$ emissions may tend to exceed the annual max values given in the standards in particular in areas where traffic is dense. This is because traffic in urban areas has an important contribution to concentration levels of $\mathrm{NO}_{2}$ and is considered to be responsible for more than half of $\mathrm{NO}_{x}$ emissions. This situation occurs as a result of increases in primary $\mathrm{NO}_{2}$ emissions given out from diesel-fueled vehicles and photochemical reaction of traffic-originated $\mathrm{NO}$ to $\mathrm{NO}_{2}$ [55].

Furthermore, increasing the compression as far as possible for maximum fuel economy raises the temperature in the combustion space, thus increasing the $\mathrm{NO}_{\mathrm{x}}$ emissions [56]. One of the significant reasons for $\mathrm{CO}$ emissions being an outdoor air pollutant is vehicle exhaust [57-58]. The fundamental reason why $\mathrm{CO}$ emissions are available between the combustion products is oxygen deficiency. Temperature factor such as the air/ fuel rate is also effective. The transformation of $\mathrm{CO}$ to $\mathrm{CO}_{2}$ cannot happen with the decrease of reaction rate in the low temperatures [56]. Since the point where active measurement was performed under the scope of this study is within an area where the effect of traffic could not be directly monitored, and due to the adverse effect of temperatures on the formation of $\mathrm{NO}_{\mathrm{x}}$ and $\mathrm{CO}$ emissions, it is considered to be mandatory to monitor $\mathrm{CO}$ and $\mathrm{NO}_{2}$ emissions and take necessary precautions, when needed, against the possibility that these concentrations may exceed the limit values specified in the standards - in particular in areas where traffic is dense.

\section{Conclusions}

This study was performed by modelling P\&A-sourced $\mathrm{CO}$ and $\mathrm{NO}_{\mathrm{x}}$ emissions by the AERMOD, ISCST-3, and CALPUFF models, and P\&A\&L-sourced $\mathrm{CO}$ and $\mathrm{NO}_{\mathrm{x}}$ emissions by the AERMOD and ISCST- 3 models.

As a result of the studies, when the results obtained with modelling all P\&A sources by three programs are analyzed, the highest annual concentration of AERMOD, ISCST-3, and CALPUFF were found as 128.82, 86.96 , and $201.30 \mu \mathrm{g} / \mathrm{m}^{3}$ for $\mathrm{CO}$, and $7.56,26.31$, and $6.10 \mu \mathrm{g} / \mathrm{m}^{3}$ for $\mathrm{NO}_{\mathrm{x}}$, respectively. On the other hand, when the results obtained with modelling all P\&A\&L sources by two programs are investigated, the highest annual concentrations of AERMOD and ISCST-3 were found as 155.12 and $92.46 \mu \mathrm{g} / \mathrm{m}^{3}$ for $\mathrm{CO}$, and 166.93 and $89.98 \mu \mathrm{g} /$ $\mathrm{m}^{3}$ for $\mathrm{NO}_{\mathrm{x}}$, respectively.

When contributions of the pollutant sources on pollution are evaluated, it was observed that area sources and line sources are more predominant than other sources for $\mathrm{CO}$ and $\mathrm{NO}_{\mathrm{x}}$ emissions, respectively, according to the annual time option (although numerical values calculated according to the modelling programs change). 
When the distribution maps are analyzed, it is determined that $\mathrm{CO}$ emissions center around the area $\mathrm{N} 2$ and $\mathrm{NO}_{\mathrm{x}}$ emissions around the areas $\mathrm{N} 1$ and N2. This is important because these areas contain the residential areas of the district. Therefore, in the study, the predicted and observed values were also compared with national and international limit values and determined to meet these limit values. It is a fact that EU air quality standards have not yet been obtained in many cities, although problems have been partially removed depending on certain precautions taken and, accordingly, national pollution limit values have been provided. Therefore, it is deemed to be important to perform such studies and specify pollution status in terms of taking the necessary measures for the future and determining the extent of the problem.

According to the results obtained by evaluating performances of the models with FB, MS, and MG statistical methods, performance sorting for $\mathrm{NO}_{\mathrm{x}}$ emissions was found as ISCST-3 $>$ CALPUFF $>$ AERMOD, while for $\mathrm{CO}$ emissions they are given as CALPUFF $>$ AERMOD $>$ ISCST-3. However, it is not correct to distinguish between performance of a model for an application and that of another model accurately, although such a result was obtained within the scope of this study. This is because the model selection depends on information such as specific properties of the study area (its meteorology, topography), content of information to be obtained by programming (whether short-term predictions such as hourly, daily, or long-term predictions such as annual ones are to be obtained), existing data entries (sublayer meteorological files, upper layer meteorological files), type of pollutant to be modelled, type of source, and range of distribution. However, interpretations can be made with respect to usage of the models. It is harder to use the Lagrangian puff model since it requires more data entries, a better computer, and more effort, although Gaussian models are easy to use, require less user decision, and can be performed with a cheaper computer [11]. In addition, AERMOD and ISC steady-state models are suggested by the U.S. EPA for close ranges $(<50 \mathrm{~km})$ and CALPUFF Lagrangian puff model for long ranges $(>50 \mathrm{~km})$ [37].

Use of such modellings has been inevitable at the present time in the sense that air quality in the study is determined using mathematical methods and mapping, without the use of expensive and demanding methods such as measurement; in particular, future planning activities have been made; it can be specified how air pollutants measured within the scope of the clean air action plans are distributed and where they can travel furthest. However, some limitations exist also in this method.

One of these limitations is emission factors used to calculate emissions. Adapting the data of America and Europe to emissions factors for Turkey is useful in cases where there is no other option. However, these factors, which may vary from one process to another due to differences in technology as well as raw materials, should be prepared for each region. This will make the results more reliable. Another limitation is lack of meteorological and topographical data of the study area. In particular, an inadequate number of meteorological stations and missing and/or incorrect data taken from the stations do significantly affect the modelling results. Furthermore, topography of the region may be inadequate in identifying the urbanization rapidly and irregularly evolving in our country, although it enables us, as a functionality of the modelling programs, to download information from satellite data to the computer via internet and run them. Therefore, whether the topographic data used for modelling is updated emerges as having an important impact on the results of modelling. Predictions of these models can be improved by obtaining actual data for input parameters [59-60]. Also, problems can be eliminated by combining the model results with the measurement results.

Under the scope of this study, being traffic-sourced emissions not modelled in the CALPUFF VIEW 5.8 program, one of the programs used in modelling was seen as a major shortcoming. Furthermore, area and volume sources that can be used instead of line sources are limited by the number 200, and this is restrictive in modelling studies of areas where two ways are available with a total length up to $50 \mathrm{~km}$, just like this study. For this reason, it will be appropriate to add into such a program supported by the EPA those applications that can model trafficsourced emissions. Also, data used in this program are quite complicated and difficult to obtain for our country. Conversion of meteorological and topographical input data obtained in the conditions of our country to the formats that can be used in particular by the CALMET program is a very demanding and time-consuming task. In order to overcome this problem, region-specific meteorological data can be obtained by WEBLAKES, distributor of the CALPUFF VIEW program; however, this introduces additional costs for the studies. As a solution, it is considered to be convenient to produce plug-in software that will ensure the program to be used equally worldwide and can run the program with an input data as simple as AERMOD, particularly. On the other hand, the CALMET program provided together with the CALPUFF VIEW 5.8 version has not an application to plot a wind rose by using available data, in contrast to the meteorological utility programs such as AERMET and RAMMET. This does not give the opportunity to make a comparison with wind roses obtained by two other programs. In conclusion, it can be deemed to be a disadvantage for the programs not having a saving option. Saving the study on the computer at certain periods by the program will allow the program to be closed and loaded at any time.

\section{Acknowledgements}

This research was financially supported by the Scientific Research Projects Unit of Kocaeli University (project No. 2009/55). 


\section{References}

1. AUGILERA X., BASAGANA T.M., PAY D., AGIS L., BOUSO M., FORASTER M., RIVERA M., BALDASANO J.M., KUNZLI N. Evaluation of the CALIOPE air quality forecasting system for epidemiological research: The example of $\mathrm{NO}_{2}$ in the province of Ginona (Spain). Atmos Environ 72, 134, 2013.

2. RUSSO A., TRIGO R.M., HARTINS H., MENDES M.T. $\mathrm{NO}_{2}, \mathrm{PM} 10$ and $\mathrm{O}_{3}$ urban concentrations and its association with circulation weather types in Portugal. Atmos Environ 89, 768, 2014.

3. DHOLAKIA H.H., PUROHIT P., RAO S., GARG A. Impact of current policies on future air quality and health outcomes in Delhi, India. Atmos Environ 75, 241, 2013.

4. WEB-1: The Environment and Forest Ministry, the General Directorate of Environmental Management. Clean Air Action Plan 2010-2013. http://www. ormansu.gov.tr/osb/Files/duyuru/ anasayfaDuyurular/ TemizHava/TemizHavaEylemPlani.pdf, TemizHava/ TemizHavaEylemPlani.pdf, Accessed: 17 April 2015.

5. WEB-2: Eskişehir Province Clean Air Plan 2011-2014. http://www.temizhava.anadolu.edu.tr/ Eskisehir-ili-TemizHava-Plani.pdf, Accessed: 10 April 2015.

6. THUNIS P., PEDERZOLIA., PERNIGOTTID. Performance criteria to evaluate air quality modeling applications. Atmos Environ 59, 476, 2012.

7. BENTAYEB M., STEMPFELET M., WAGNER V., ZINS M., BONENFANT S., SONGEUR C., SANCHEZ O., ROSSO A., BRULFERT G., RIOS I., CHAXEL E., VIRGA J., ARMENGAUD A., ROSELLO P., RIVIERE E., BERNARD M., VASBIEN F., DEPROST R. Retrospective modeling outdoor air pollution at a fine spatial scale in France, 1989-2008. Atmos Environ 92, 267, 2014.

8. HAGAN N., ROBINS N., HSU-KIM H., HALABI S., MORRIS M., WOODALL G., ZHANG T., BACON A., RICHTER D.D.B., VANDERBERG J. Estimating historical atmospheric mercury concentrations from silver mining and their legacies in present day surface soil in potosi Bolivia. Atmos Environ 45 (40), 7619, 2011.

9. KESARKAR A.P., DALVI M., KAGINALKAR A. OJHA A. Coupling of the weather research and forecasting model with AERMOD for pollutant dispersion modeling. A case study for PM10 dispersion over pune India. Atmos Environ 41 (9), 1976, 2007.

10. [COELHO M.C., FONTES T., BANDERIA J.M., PEREINA S.R., TCHEPEL O., DIAS D., SA E., AMORIM J.H., BARREGO C. Assessment of potential improvements on regional air quality modeling related with implementation of a detailed methodology for traffic emission estimation. Sci Total Environ 470-471, 127, 2014.

11. CAPELLI L., SIRONI S., ROSSO R.D., GUILLOT M. Measuring odours in the environment vs. dispersion modeling: A review. Atmos Environ 79, 731, 2013.

12. SANGÜN L. An investigation on principal component, discriminate and cluster analyses and their application on ecological data. PhD Thesis. Department of aquaculture science institute of natural and applied sciences Çukurova University. Turkey, 2007.

13. WEB-3: http://www.nufusu.com/ilce/korfez_kocaelinufusu. Accessed: 7 September 2015.

14. WEB-4: http://www.kocaeli.bel.tr/icerik/korfez/2419/ 19328. Accessed: 2 April 2015.

15. WEB-5: Satellite image by google earth. Accessed: 21 April 2015.
16. MOKHTAR M.M., HASSIM M.H., TAIB R.M. Health risk assessment of emission from a coal fired power plant using AERMOD modeling. Process Saf Environ 92, 2, 2014.

17. HUERTAS J.I., HUERTAS M.E., CERVANTES G., DIAZ $\mathrm{J}$. Assessment of the natural sources of particulate matter on the opencast mines air quality. Sci Total Environ 493 (2000), 1047, 2014

18. STEIN A.F., ISAKOV V., GODOWITCH J., DRAXLER R.R. A hybrit modeling approach to resolve pollutant concentrations in an urban area. Atmos Environ 41 (40), 9410, 2007

19. TARTAKOVSKY D., BRODAY D.M., STERN E. Evaluation of AERMOD and CALPUFF for predicting ambient concentrations of total suspended particulate matter (TSP) emissions from quarry in complex terrain. Environ Pollut 179, 138, 2013.

20. ABRIL G.A., WANNAZ E.D., MATEOS A.C., PIGNATA M.L. Biomonitoring of airborne particulate matter emitted from a cement plant and comparison with dispersion modelling results. Atmos Environ 82, 154, 2014.

21. AL-RASHIDI M.S., NASSEHI V., WAKEMAN R.J. Investigation of the efficiency of existing air pollution monitoring sites in the state of Kuwait. Environ Pollut 138 (2), 219, 2005.

22. ÇETIN, Ş. Dispersion modelling of $\mathrm{NO}_{x}$ emissions in Kocaeli. PhD Thesis. Institute of science department of environmental engineering. Kocaeli University. Turkey. 2006.

23. ABDUL-WAHAB S.A., CHAN K., ELKAMEL A., AHMADI L. Effects of meteorological conditions on the concentration and dispersion of an accidental release of $\mathrm{H}_{2} \mathrm{~S}$ in Canada. Atmos Environ 82, 316, 2014.

24. CURCI G., CINQUE G., TUCELLA P., VISCONTI G., VERDECCHIA M., IARLORI M., RIZI V. Modelling air quality impact of a biomass energy power plant in a mountain valley in central Italy. Atmos Environ 62, 248, 2012.

25. AINSLE B., JACKSON P. The use of an atmospheric dispersion model to determine influence region in the Prince George, B.C air shed from the burning open waste piles. J Environ Manage 90 (8), 2393, 2009.

26. CHOI Y., FERNANDO H. Simulation of smoke plumes from agricultural burns: application to the San Luis/Rio Colorado air shed along the U.S./Mexico border. Sci Total Environ 388 (1-3), 270, 2007.

27. MACHINTOSH D.L., STEWART J.H., MYATT T.A., SABATO J.E., FLOWERS G.C., BROWN K.W., HLINKA D.J., SULLIVAN D.A. Use of CALPUFF for exposure assessment in a near-field, complex terrain setting. Atmos Environ 44 (2), 262, 2010.

28. ROJAS A.L.P., VENEGAS L.E. Dry and wet deposition of nitrogen emitted in Buenos Aires city to water of de la Plata River. Water Air Soil Poll 193, 175, 2008.

29. British Columbia Ministry of Environment, Environmental Protection Division Environmental Quality Branch. Air Protection Section. Guidelines for Air Quality Dispersion Modelling in British Columbia. March 2008.

30. Emissions report 2009. Kocaeli Governorship Provincial Directorate of Environment and Urbanization. Date of Visit: December 2010.

31. Kocaeli provincial environmental status report. Kocaeli Governorship Provincial Directorate of Environment and Urbanization. 2008.

32. USEPA. Technology transfer network clearinghouse for inventories and emission factors. Fifth Edition. 1998. 
33. The Department of Strategic Development Division of Transport Cost and Productivity. The annual average daily traffic values of highways and state roads transportation information according to traffic zone in 2008. May 2009.

34. BOTLAGUDURU V.S.V. Comparison of AERMOD and ISCST3 models for particulate emissions from ground level sources. Master of Science. Texas A\&M University, Texas USA. 2009.

35. WEB-6: RADONJIC Z., GARISTO N. C. An assessment of the suitability of air dispersion models to predict contaminant concentrations in air due to industrial emissions. www.iitk. ac.in/che/jpg/papersb. Accessed: 01 January 2012.

36. OZKURT N., SARI D., AKALIN N., HILMIOGLU B. Evaluation of impact of $\mathrm{SO}_{2}$ and $\mathrm{NO}_{2}$ emissions on the ambient air-quality in the Çan-Bayramiç region of northwest Turkey during 2007-2008. Sci Total Environ 456-457, 254, 2013.

37. ROOD A.S. Performance evaluation of AERMOD, CALPUFF, and legacy air dispersion models using the winter validation tracer study dataset. Atmos Environ 89,707, 2014.

38. MASURAHA A. Evaluation of the AERMOD model and examination of required length of meteorological data for computing concentrations in urban areas. Master of Science in Civil Engineering. The University of Toledo. Spain. 2006.

39. GHANNAM K., EL-FADEL M. Emissions characterization and regulatory compliance at an industrial complex: An integrated MM5/CALPUFF approach. Atmos Environ 69, 156, 2013.

40. IM U., YENIGÜN O. An application of a puff dispersion model on power plant emissions in Yatagan region, Turkey. Int J Environ Pollut 23 (3), 314, 2005.

41. DREW G.H., SMITH R., GERARD V., BURGE C., LOWE M., KINNERSLEY R., SNEATH R., LONGHURST P.J. Appropriateness of selecting different averaging times for modelling chronic and acute exposure to environmental odours. Atmos Environ 41, 2870, 2007.

42. EL-FADEL M., ABI-ESBER L., AYASH T. Managing emissions from highly industrialized areas: Regulatory compliance under uncertainty. Atmos Environ 43 (32), 5015, 2009.

43. CUI H., YAO R., XU X., XIN C., YANG J. A tracer experiment study to evaluate the CALPUFF real time application in a near field complex terrain setting. Atmos Environ 45 (39), 7525, 2011.

44. HONAGANAHALLI P.S., SEIBER J.N. Measured and predicted air shed concentrations of methyl bromide in an agricultural valley and applications to exposure assessment. Atmos Environ 34 (21), 3511, 2000.

45. HAO J., HE D., WU Y., FU L., HE K. A study of the emission and concentration distribution of vehicular pollutants in the urban area of Beijing. Atmos Environ 34, 453, 2000.
46. BELLASIO R., MAFFEIS G., SCIRE J.S., LONGANI M.G., BIANCONI R., QUANNANTA N. Algorithms to account for topographic shading effects and surface temperature dependence on terrain elevation in diagnostic meteorological models. Bound-Lay Meteorol 114 (3), 595, 2005.

47. DEMIRARSLAN, K.O. Determination of air quality and air pollutant sources in Körfez District in Kocaeli. PhD Thesis. Institute of science. Department of environmental engineering. Kocaeli University. Turkey, 2012.

48. HUERTAS J.I., HUERTAS M.E., IZQUIERDO S., GONZALES E.D. Air quality impact assessment of multiple open pit coal mines in northern Colombia. J Environ Manage 93 (1), 121, 2012.

49. LORBER M., ESCHENROEDER A., ROBINSON R. Testing the USA EPA's ISCST-3 version 3 model on dioxins: A comparison of predicted and observed air and soil concentrations. Atmos Environ 34 (23), 3995, 2000.

50. SCHUTTE A., JAIIN R., WALSH C. CALPUFF modelling for the Williams Lake air shed. Ministry of Environment Cariboo Region. 405-0145, 24, 2005.

51. Air Quality Assessment and Management Regulation, T.C. The Ministry Of Environment and Urban Planning. R.G.S. 26898 R.G.T. 06.06.2008.

52. WHO Air quality guidelines for particulate matter, ozone, nitrogen dioxide and sulfur dioxide. World Health Organization. 2006.

53. Air Quality Standards. European Commission. 2012.

54. National Ambient Air Quality Standards. U.S. Environmental Protection Agency. 2012.

55. DRAGOMIR C.M., CONSTANTIN D-E., VOICULESCU M., GEORGESCU L.P., MERLAUD A., ROOZENDAEL A.M. Modeling results of atmospheric dispersion of $\mathrm{NO}_{2}$ in an urban area using METI-LIS and comparison with coincident mobile DOAS measurements. Atmos Pollut Res 6, 503, 2015.

56. TOPGÜL T., YÜCESU H.S., OKUR M. The experimental investigation of the effects of operating parameters on exhaust emissions on a spark ignition engine, J Polytec, 8 , 43, 2005.

57. OZENSOY A., HEPER G. Carbon Monoxide Poisoning. AIBU Izzet Baysal Medical Journal 4 (2), 54, 2009.

58. VARDOULAKIS S., FISHER B.E.A., PERICLEOUS K. GONZALEZ-FLESCA N. Modelling air quality in street canyons: a review. Atmos Environ 37, 155, 2003.

59. TAYANC M. Air quality modelling in Turkey, Air Pollut Res J 2 112, 122, 2013.

60. YEGNAN A. WILLIAMSON D.G. GRAETTINGER A.J. Uncertainty analysis in air dispersion modeling. Environ Modell and Softw 17 (7), 639, 2002. 